\title{
Values and Planned Behaviour of the Romanian Organic Food Consumer
}

\author{
Cristina Fleșeriu ${ }^{1, *}$, Smaranda Adina Cosma ${ }^{1}$ and Vlad Bocăneț ${ }^{2}$ \\ 1 Department of Hospitality Service, Faculty of Business, Babeș-Bolyai University, Horea Str., 7, \\ RO-400174 Cluj-Napoca, Romania; smaranda.cosma@tbs.ubbcluj.ro \\ 2 Department of Industrial Engineering, Faculty of Machine Building, Technical University of Cluj-Napoca, \\ Memorandumului Str., 28, RO- 400114 Cluj-Napoca, Romania; vlad.bocanet@tcm.utcluj.ro \\ * Correspondence: cristin.fleseriu@tbs.ubbcluj.ro
}

Received: 6 February 2020; Accepted: 21 February 2020; Published: 25 February 2020

check for updates

\begin{abstract}
Romanian consumers have started to buy and consume more organic products. Their decision-making process is influenced by multiple variables. The theory of planned behaviour is widely accepted and used to predict behaviours in certain contexts, including the buying of organic food products. Other researchers have identified values that the consumer of organic products hold and that influence their buying behaviour. This study analyses the factors that have an impact on buying intention and behaviour of Romanian organic products from these two perspectives. A proposed model was designed by combining the two frameworks. It was evaluated by using structural equation modelling with the SmartPLS 3 software package (v. 3.2.7, SmartPLS GmbH, Bönningstedt, Germany, 2017). Results confirm the model proposed in the theory of planned behaviour while integrating the relationships of consumer values. Health consciousness was found to have a significant effect both on buying intention as well as on personal attitude. Food safety has a significant effect on buying intention regardless of personal attitude. Environmental concerns, social consciousness, perception of quality and lifestyle although important in personal attitude, do not affect buying intention directly.
\end{abstract}

Keywords: organic food; consumer behaviour; theory of planned behaviour; consumer values

\section{Introduction}

Today, agricultural production needs to be done considering food security and the protection and preservation of the environment. Food is the main source of nutrients for people while also being a basic medicine that helps maintain and regain one's health [1]. The main supplier of "living food" is organic agriculture [2].

The consumption of organic food can increase the opportunities for businesses in this field, by creating significant benefits to the economy [3,4]. Countries worldwide have seen this potential. In 2017, Romania had 258.471 hectares of organic agricultural land representing $12.63 \%$ of the country's total agricultural land [5]. In 2011, the export of organic produce reached 200 million euro and retail sales reached 41 million euro in 2016. Even if, the country has traditionally been important grower and exporter of organic crops, the internal market is just developing [5].

The demand for organic products among Romanian consumers started to trend upwards in recent years and will continue to grow [6]. The increasing demand for organic products has been impacted by many variables such as: Romania's growing economy, a higher focus on organic products among retailers and consumer awareness [6]. Demand has been rising proportionally with the level of disposable income and urbanization [6]. Imports are driven by increasing demand and the lack of variety in domestic products [6]. Whether for personal reasons or because of different influences such 
as social media or friends and family, Romanian consumers' behaviour has changed and they are now buying organic products more often and prefer the companies that adopt a sustainable strategy [7]. That is the reason why the consumer buying intention and behaviour needs to be reconsidered, in order to keep up with the changing trends and consumer decision-making processes.

The consumer's buying behaviour is linked to their personal needs [8]. Marketers must identify the needs of their customers, how they acquire information about different products and how they use it to select the product they want [9]. Many studies have tried to identify the main factors that influence the decision-making process when buying organic products. Hughner et al. [10] identify five main purchase motives that influence consumer preference for organic foods: health concerns (including nutritional and safety), better taste, environmental concerns, animal welfare, concerns and support of the local economy. Chiciudean et al. [11] grouped the major motivators in health motivations, ethical concerns, taste, freshness, quality and sustainability concerns while Rana and Paul [12] analyse the highest number of consumer values such as: health consciousness and expectations of well-being, quality and safety, environmental friendliness and ethical consumerism, fashion trends and unique lifestyle and social consciousness.

In 1985, Ajzen developed the theory of planned behaviour (TPB) [13] and in a later paper [14] he developed a framework to predict behaviours in specific contexts. He found that behavioural intentions are predicted with a high degree of accuracy by three factors: personal attitude towards that behaviour, subjective norms and perceived behavioural control [14]. The theory of planned behaviour has become one of the most influential models for predicting human social behaviour [15]. There are authors that used the theory of planned behaviour for analysing the consumer behaviour of organic food products and considered it as a good starting point for modelling the consumer behaviour (Table 1).

Table 1. Literature summary on values and the theory of planned behaviour when buying organic food products.

\begin{tabular}{|c|c|c|c|}
\hline Components & Elements & No. of Studies Found & Sources (Year) \\
\hline \multirow{6}{*}{ Values } & $\mathrm{HC}$ & 10 & $\begin{array}{c}\text { Tarkiainen and Sundqvist [16] (2005), } \\
\text { Chen [17] (2007), Aertsens et al. [18] } \\
\text { (2009) Thøgersen and Zhou [19] (2012), } \\
\text { Irianto [20] (2015), Yadav and Pathak } \\
\text { [21] (2016), Tuan and Vinh [22] (2016), } \\
\text { Asif et al. [23] (2018), Singh and Verma } \\
\text { [24] (2017), Bagher et al. [25] (2018), } \\
\text { Wang et al. [26] (2019) }\end{array}$ \\
\hline & $\mathrm{EC}$ & 9 & $\begin{array}{l}\text { Laureti and Benedetti [8] (2018), Chen } \\
\text { [17] (2007), Thøgersen and Zhou [19] } \\
\text { (2012), Irianto [20] (2015), Yadav and } \\
\text { Pathak [21] (2016), Tuan and Vinh [22] } \\
\text { (2016), Asif et al. [23] (2018), Paul et al. } \\
\text { [27] (2015), Maichum et al. [28] (2016) }\end{array}$ \\
\hline & FS & 1 & Aertsens et al. [18] (2009) \\
\hline & PQ & 2 & $\begin{array}{c}\text { Chen [17] (2007), Thøgersen and Zhou } \\
\text { [19] (2012) }\end{array}$ \\
\hline & $\mathrm{L}$ & 1 & Bagher et al. [25] (2018) \\
\hline & SC & 0 & \\
\hline
\end{tabular}


Table 1. Cont.

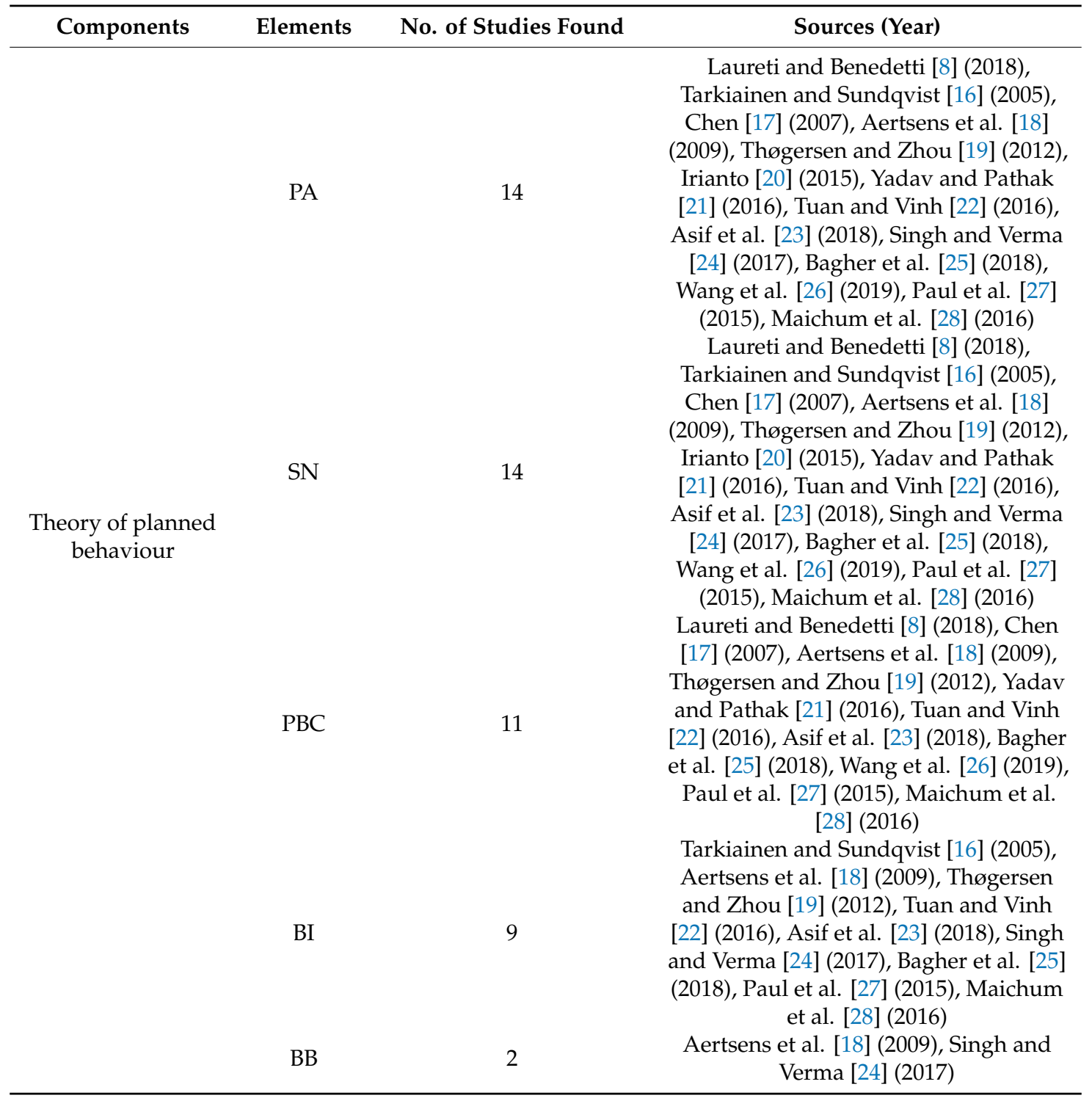

Note: "HC"—health consciousness, "EC"—environmental concern, "FS"—food safety, "PQ"—perception of quality, "L"-lifestyle, "SC"—Social consciousness, "PA"—-personal attitude, "SN" — subjective norms, "PBC"—perceived behaviour control, "BI"- - buying intention, "BB"- - buying behaviour.

Most of the studies analyse the relationship between the theory of planned behaviour and some of the customer values. Health consciousness and environmental concern were analysed most frequently in combination with the TPB. Some of the researchers [24-27] propose the addition to the model of other relevant variables and use them in predicting buying intention as future research directions. Other studies have considered more consumer values but have not placed them in the context of the theory of planned behaviour. This study aims to analyse the buying intention of the Romanian organic food product consumer from while combining the theory of planned behaviour with consumer values. 


\section{Literature Review and Hypothesis}

\subsection{Research Components}

\subsubsection{Consumer Values}

Consumers attribute value to a product by assessing its utility based on the perception of what is received and what is given and focus on the benefits or the worthiness of using a specific product [29]. Because each consumer has a different value system, their behaviour will differ depending on said values [30]. Values can influence the individual's attitude [31] and can provide a basis for consumers' evaluations and preferences for products. Some values influence the attitude toward organic food products in a positive way: health consciousness, environmental concerns, food safety, perception of quality, lifestyle and social consciousness [12]. Therefore, the current study proposes that these values may influence the consumer's attitude toward purchasing organic food products.

Health consciousness. Health consciousness is "the degree to which health concerns are integrated into a person's daily activities" [32]. Consumers that are health conscious, put an effort to lead a healthy life [33]. Health conscious consumers care about their state of wellbeing and are willing to improve their health and quality of life, by preventing ill health for example [33]. This value stems from the consumer's feeling of "freedom from chemicals" [34], but the level of individual health consciousness is closely related to how people look for and how they respond to health information [35].

Environmental concerns. Environmental consciousness was defined as "the degree of emotional involvement in environmental issues; it taps the individuals' affective response towards environmental protection" [36]. Marketers know that environmental concern has become an important factor, and it is much easier to target this type of consumer [37]. Those customers that have high environment concerns will know to ask for quality obtained in a sustainable way and will buy environmentally friendly products [38]. They are also willing to change their buying behaviour to improve the environment and pay a higher price for organic food products [26,39].

Food safety. Food safety means guarding national food supply chains from hazardous microbial and chemical agents [40]. It is considered as being a challenge because of the global dimensions of food supply chains, the need for reducing food waste and efficient use of natural resources.

Perception of quality. When defining the quality of a food product, consumers consider not just intrinsic aspects such as taste, smell and other properties, but also external factors such as origin and labelling [41,42]. Differences in quality assessment have consequences on the consumers' behaviour, beliefs and attitudes [42]. Dietary patterns, food preparation and purchase decisions are influenced by the expected quality [43].

Lifestyle. Lifestyle refers to the behaviourally oriented facets of people [44]. Each lifestyle has its particularities based on different activities, interests and opinions [45]. Aspects such as cultural affiliation, social status, family background, personality, motivation, cognition, and marketing stimuli influence lifestyle [46]. Fullerton \& Dodge found that it has a significant influence on consumer behaviour [47].

Social consciousness. Consumers buy products not just for their tangible attributes, but also for their intangible ones, such as supporting local communities and preserving traditions [48]. This ethnocentric tendency, to prefer national rather than international products, also influences buying behaviour [49]. An ethnocentric attitude represents not just an obligation to buy local-made products but can also be seen as a determinant of product perceptions [50].

\subsubsection{Personal Attitude}

Attitude is "a psychological path of evaluating a specific object with favor or disfavor" [51]. Personal attitude reflects individual preferences to perform or not a behaviour regarding general consumption or of a specific product; the more positive the attitude, the stronger the intention to express the behaviour [52]. Attitudes have two components: cognitive (thinking) and affective (feeling) $[53,54]$. 
The interaction between them influences attitude and choice [55]. Some attitudes toward different objects may rely more on affect while for others more on cognition [54]. When beliefs and feelings about an object have an opposite valence, feelings tend to predominate [56]. Also, for affective judgments, the response times are significantly shorter compared with cognitive ones, meaning that attitudes underlined by affective aspects are more accessible in the memory [54].

\subsubsection{Subjective Norms}

Subjective norms also called social norms are perceived social pressure by individuals to engage or not to engage in a specific behaviour [14]. Huda et al. defines subjective norms "as one's perceptions or assumptions about others' expectations of certain behaviours that one will or will not perform" [57]. There are two types of subjective norms: injunctive and descriptive; the theory of planned behaviour focuses on the role of injunctive norms [58]. These are normative beliefs and expectations that the groups or important references (family members, friends, co-workers, children etc.) have on one person [14]. Subjective norms are considered as being the impacts of external factors on customer intention [59] and can predict the consumer behaviour, when an individual's actions influence another consumer's behaviour [60]. People follow social norms not just because they fear social pressure, but because they give information about what behaviour is most appropriate or beneficial [61].

\subsubsection{Perceived Behavioural Control}

Perceived behavioural control (PBC) relates to the individual perception of those factors that might foster or hinder the expression of a behaviour [62]. Ajzen mentions two aspects: the control which people have over the behaviour and the way a person feels confident about performing behaviour [14]. Perceived behavioural control is linked to the level of control that a person perceives over one's behaviour [17]. A person that has a higher perceived personal control will have stronger behavioural intention to buy a product [14]. Different factors such as time, money, and skills influence perceived behavioural control [14]. People with higher behavioural control have a stronger intention towards certain behaviours [21].

\subsubsection{Buying Intention and Buying Behaviour}

According to Keller [63], the consumers' buying decision is very complex and the buying behaviour is a key point for consumers when considering and evaluating a product. This behaviour is influenced by psychological motivations [53]. When predicting the buying process, the buying intention is a significant factor [64]. When consumers decide to purchase the product, they will be driven by their intention.

Buying intention is defined as a conscious plan of action taken into consideration by consumers when they will buy [65] and requires behaviour and motivation to use it [66]. Intention is accepted as the best available predictor of human behaviour, being the pre-step that guides clients to actual purchase actions [67]. If consumers want to buy a product, they will pay more than those who have no intention to buy [68]. Also, buying intention can be influenced by price, quality and value perception [69].

\subsection{Relationship Between Research Concepts}

\subsubsection{Influence of Consumer Values on Personal Attitude and Buying Intention}

Personal attitude can contain a sum of different beliefs such as taste, healthiness and perceived benefits related to the environment [70]. When buying food products, one significant motivator is health [71]. Organic farming respects "the laws of nature" and "the laws of life", as being high-quality products, "100\% natural" without chemical synthesis as opposed to conventional agriculture [72], that can harm human health and the environment [73]. According to Paul and Rana [74], the more cognizant consumers are about their health the more positive the attitude towards purchase intention 
of organic products. Romanian consumers consider health as a major motivator for purchasing organic food products [75]. Romanians' attitudes towards organic food are generally positive and influence the consumer behaviour when taking the decision for purchasing food [75]. As a result, the authors proposed the following hypotheses:

Hypothesis 1a. Health consciousness has a significant effect on personal attitude.

Hypothesis $\mathbf{1 b}$. Health consciousness has a significant effect on buying intention.

If health consciousness is considered as being an egoistic motivator (benefits the individual or his/ her family), the environment friendliness and the ethical consumerism are more altruistic (benefits society rather than the individual). But even altruistic considerations have often a personal influence [76] and most consumers do not want to give up their personal benefit in order to contribute to the benefit of the community [71]. Consumer attitude has evolved due to ethical concerns towards the environment [77]. Environmental protection is a motivator that has led to ethical consumerism [78]. Practicing ethical consumerism inspires consumers to buy "green" products in order to fulfil their ethical responsibility [79]. Based on these assumptions, the authors propose the following hypotheses:

Hypothesis 2a. Environmental concerns have a significant effect on personal attitude.

Hypothesis 2b. Environmental concerns have a significant effect on buying intention.

Food safety can also influence the consume of organic products [80-82]. It is actively promoted by governments, healthcare industry professionals, researchers etc. [83,84]. In this regard, organic products do not contain pesticides and other crop-preserving chemicals [85]. Organic food products are regarded as being safer to eat, affecting the personal attitude towards them. Following these aspects, the hypotheses have been formulated:

Hypothesis 3a. Food safety has a significant effect on personal attitude.

Hypothesis $3 \mathbf{b}$. Food safety has a significant effect on buying intention.

Consumers consider that the authenticity of organic products depends on its natural taste and product quality [86], labelling and a separate exposition spot in the points of purchase [87]. Salleh et al. found that the product's quality and taste motivate consumers to purchase organic products [88]. Consumers are willing to pay more for an expected extra quality in product and process [89]. Considering this, the authors propose the following hypotheses:

Hypothesis 4a. Perception of quality has a significant effect on personal attitude.

Hypothesis $\mathbf{4 b}$. Perception of quality has a significant effect on buying intention.

Consuming organic products, that are expensive and exclusive has become the latest trend in the elite society of some countries. It shows that consumers with greater income have a higher purchasing power and a more luxurious lifestyle [12]. Canavari indicates that certain foods are consumed as a status symbol [90]. Starting from these assumptions, the authors propose the following hypotheses:

Hypothesis 5a. Lifestyle has a significant effect on personal attitude.

Hypothesis $\mathbf{5 b}$. Lifestyle has a significant effect on buying intention. 
Buying and consuming organic products can also be fuelled by a desire to support and strengthen the local economy and community, including greater self-reliance and independence from global corporations and supermarkets. Social consciousness can encourage the consumers to purchase organic products, in order to set an example and inspire others to change their consumption habits for the societal benefit [90]. Social influence can determine people to change one's emotions, opinions and behaviour [91]. Because of these aspects, the authors propose the following hypotheses:

Hypothesis 6a. Social consciousness has a significant effect on personal attitude.

Hypothesis $\mathbf{6 b}$. Social consciousness has a significant effect on buying intention.

\subsubsection{Relationship between Theory of Planned Behaviour Model Components}

When purchasing organic food, attitude shapes the behaviour by directly influencing the buying intention [92]. Conner and Sparks [93] discovered that food consumption is influenced by affect, while Dean et al. [94] found that both affect and cognition predict purchase intention. This means that people evaluate behaviour using not just costs and benefits, but also the positive and negative feelings generated by that behaviour [18]. In the organic food sector, studies made in different cultures and for different product categories underline the existence of a significant relationship between consumers' attitudes and purchase intentions [16]. When purchasing organic food, affect and cognition are combined in a compensatory way [94]. It means that the perceived costs of buying organic products may be offset by the positive feelings that it produces [18]. Because personal attitude has an influence on buying organic products, the following hypothesis can be drawn.

Hypothesis 7. Personal attitude has a significant effect on buying intention.

Several studies underline that subjective norms are an important determinant of buying intention for green products [27] and organic food [95]. In the case of the organic products, Zagata says that family and friends have the biggest social influence [96], while Yadav and Pathak [21] found that subjective norms do not have any significant effect on the intention to buy organic products. Armitage and Conner [52] argued that this component might be the weakest amongst the model's constructs. Based on the discussion above, the following hypothesis can be formulated:

Hypothesis 8. Subjective norms have a significant effect on buying intention.

For organic products, high price and low availability are considered barriers [97], but researchers have different perspectives regarding buying intention; Dowd and Burke [98] found an association between the two, while Yazdanpanah and Forouzani [99] found no significant correlation between them. Olsen [100] pointed out that consumer food purchase is influenced by self-efficacy and convenience/ availability. Researchers have concluded that there is a positive relationship between purchase intention and the ability of the individual to control their behaviour [101]. Taken into consideration the fact that perceived behavioural control influences the buying behaviour the authors propose the following hypothesis:

Hypothesis 9. Perceived behavioural control has a significant effect on buying intention.

Intention can determine behaviour with a high accuracy [14]. Intention has been assumed to be a strong behavioural predictor, but there are situations when this does not apply. This effect is defined as the intention-behaviour gap: when intention may not necessarily lead to the desired behaviour [102]. Still, there are researchers [103] that found a high degree of correlation between intention and behaviour. When analysing the buying behaviour for organic products, researchers have identified a significantly 
positive relationship between buying intention and buying behaviour [104]. Because buying intention can influence buying behaviour, the following hypothesis can be drawn:

Hypothesis 10. Buying intention has a significant effect on buying behaviour.

\subsection{Conceptual Model}

In this study the authors proposed, based on these hypotheses, the conceptual model presented in Figure 1. The study starts with the theory of planned behaviour and, as a result of the literature review, the authors include the six main values that affect both personal attitude and buying intention.

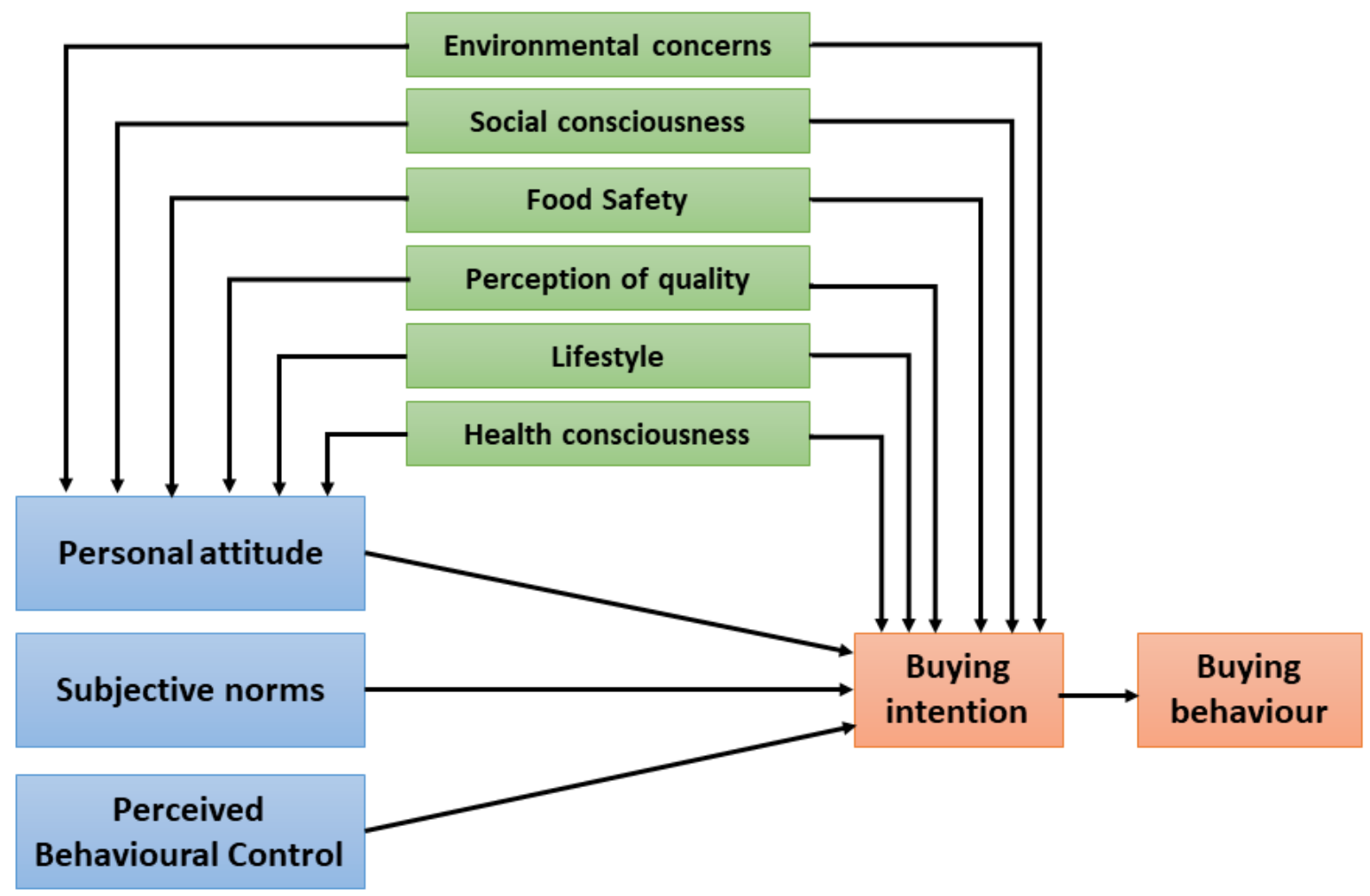

Figure 1. The proposed conceptual framework.

\section{Materials and Methods}

\subsection{Sampling Method and Data Collection}

A descriptive and causal research was performed to identify what are the significant factors that influence the Romanian consumer behaviour when purchasing organic fruits and vegetables Data were acquired online by means of an online questionnaire disseminated through the social platform Facebook between September and December 2019. People interested in organic products were identified by their membership of closed groups relating to the subject. The non-probabilistic method of snowball sampling was used because access to the closed groups was not easily attainable. Each respondent was asked to forward the questionnaire to other interested parties, gaining in this way access to active organic product consumers. Anticipating a moderate effect size (0.3) with a desired statistical power level of 0.9 and a p-value of 0.05 , the sample calculation resulted in a minimum sample size of 248, in order to detect the desired effect [105]. A total of 330 respondents filled in the questionnaires. The data were checked for unengaged responses by looking at the standard deviation for each question set, resulting in 325 valid responses. 


\subsection{Scale Development}

The questionnaire contains items relating to personal attitude, subjective norms perceived behavioural control, consumer buying intention and behaviour as well as consumer values (environmental concerns, social consciousness, food safety, perception of quality, lifestyle and health consciousness). The items were adapted from research on the theory of planned behaviour and consumer values (see Table 2). The scale items were validated in previous research papers by different authors. Although the authors assumed that the groups contained only organic product consumers, a selection variable was added in order to check this assumption. The item asked respondents to indicate how often they buy organic products. Persons who said that they have never bought organic products were considered non-consumers. A seven-point Likert scale (1-total disagreement, 7-total agreement) was used to quantify the level of agreement with statements representing all measured items. One idem ("Organic products have a longer shelf life") was reverse coded in order to align with the direction of the other items. Socio-demographic information such as: gender, age, monthly income, studies, marital status, number of children and children's' age was also collected. The draft questionnaire was pre-tested on a focus group of 5 organic product consumers and based on the respondents' comments and suggestions, it was adapted in terms of language and translation.

Table 2. Questionnaire items and supporting literature.

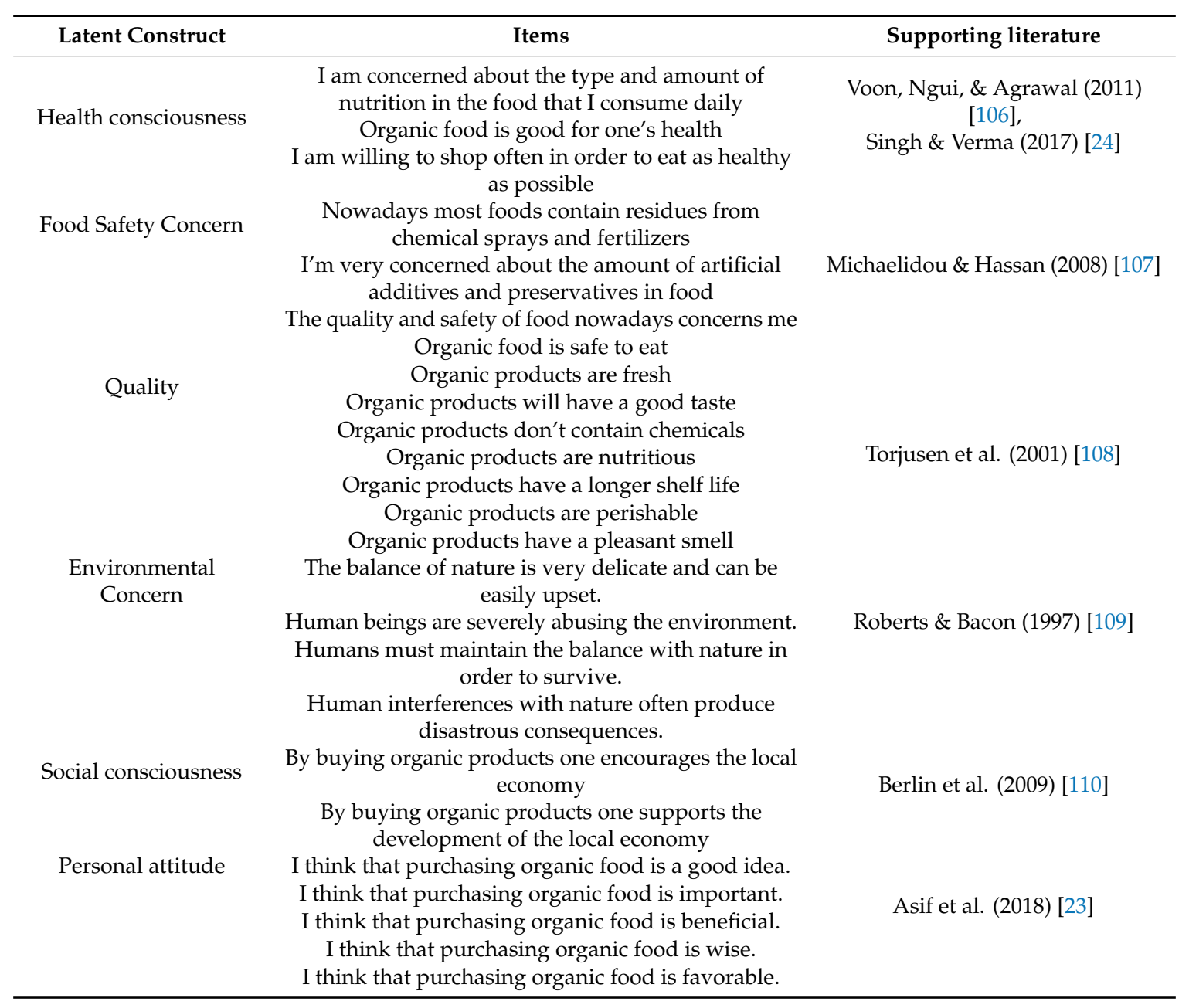


Table 2. Cont

\begin{tabular}{|c|c|c|}
\hline Latent Construct & Items & Supporting literature \\
\hline Subjective Norm & $\begin{array}{l}\text { My family thinks that I should buy organic products } \\
\text { rather than non-organic ones. } \\
\text { Most people I value would buy organic products } \\
\text { rather than non-organic products. } \\
\text { People I value think I should buy organic products. } \\
\text { Most friends whose opinions regarding diet are } \\
\text { important to me, think that I should buy organic } \\
\text { products. }\end{array}$ & Asif et al. (2018) [23] \\
\hline Lifestyle & $\begin{array}{l}\text { Purchasing organic products makes me feel superior. } \\
\text { I intend to consume organic products in the future }\end{array}$ & Bai et al. (2019) [111] \\
\hline Buying Intention & $\begin{array}{c}\text { I am always interested in buying more organic food } \\
\text { for the family's needs } \\
\text { I always intend to look for organic foods, although } \\
\text { outside the city }\end{array}$ & Singh \& Verma (2017) [24] \\
\hline $\begin{array}{l}\text { Actual Buying } \\
\text { Behaviour }\end{array}$ & $\begin{array}{l}\text { I have been a regular buyer of organic foods } \\
\text { I still buy organic food even though conventional } \\
\text { alternatives are on sale }\end{array}$ & Singh \& Verma (2017) [24] \\
\hline $\begin{array}{l}\text { Perceived Behavioural } \\
\text { Control }\end{array}$ & $\begin{array}{c}\text { I never mind paying premium price for organic } \\
\text { products } \\
\text { If I wanted to, I could buy organic products instead } \\
\text { of conventional ones. } \\
\text { I think it is easy for me to buy organic products. } \\
\text { It is mostly up to me whether to buy organic } \\
\text { products. }\end{array}$ & Asif et al. (2018) [23] \\
\hline
\end{tabular}

\subsection{Model Specification and Data Analysis}

Because of the number of variables considered and the complexity posed by the relationship between them, the authors used Structural Equation Modelling with Partial Least Squares (SEM-PLS) as the modelling method. It is widely used in many social science disciplines including marketing and it allows researchers to "estimate complex models with many constructs, indicator variables, and structural paths without imposing distributional assumptions on the data" [112]. It can be used to evaluate the measurement of latent variables and the relationship between them [113]. The model was estimated and evaluated by using the SmartPLS 3 software package. The sample was first analysed from a socio-demographic standpoint by using descriptive statistics.

\section{Results}

The socio-demographic structure of the sample is presented in Table 3. Three percent (10) of respondents said that they have never bought organic products. By removing them it was ensured that the results apply to consumers of organic products and that they were not skewed by the responses of people that never bought organic products. Most respondents have ages between 24 and 38 years $(58 \%)$, women (76\%), with a university education (57\%) earning between 460 and 670 Euro $(27 \%)$ that are married or in a relationship (64\%) with no children $(65 \%)$. 
Table 3. Socio-demographic structure of the sample.

\begin{tabular}{|c|c|c|c|}
\hline Category & Items & Frequency & $\%$ \\
\hline \multirow{6}{*}{ Age categories } & $<24$ & 75 & $24 \%$ \\
\hline & $24-38$ & 184 & $58 \%$ \\
\hline & $39-58$ & 50 & $16 \%$ \\
\hline & $59-74$ & 5 & $2 \%$ \\
\hline & $>74$ & 1 & $0 \%$ \\
\hline & Female & 240 & $76 \%$ \\
\hline \multirow[t]{2}{*}{ Sex } & Male & 74 & $23 \%$ \\
\hline & No response & 1 & $0 \%$ \\
\hline \multirow{4}{*}{ Studies } & Highschool & 34 & $11 \%$ \\
\hline & Post-high-school & 3 & $1 \%$ \\
\hline & University & 179 & $57 \%$ \\
\hline & Post-university & 99 & $31 \%$ \\
\hline \multirow{5}{*}{ Income * } & $<250$ Euro & 25 & $8 \%$ \\
\hline & 250-460 Euro & 57 & $18 \%$ \\
\hline & 460-670 Euro & 86 & $27 \%$ \\
\hline & 670-880 Euro & 75 & $24 \%$ \\
\hline & $>880$ Euro & 72 & $23 \%$ \\
\hline \multirow{3}{*}{ Marital status } & Single & 113 & $36 \%$ \\
\hline & In a relationship/Married & 202 & $64 \%$ \\
\hline & 0 & 206 & $65 \%$ \\
\hline \multirow{3}{*}{$\begin{array}{l}\text { Number of } \\
\text { children }\end{array}$} & 1 & 72 & $23 \%$ \\
\hline & 2 & 35 & $11 \%$ \\
\hline & $\geq 3$ & 2 & $1 \%$ \\
\hline \multirow{4}{*}{ Children ages } & Not applicable & 204 & $65 \%$ \\
\hline & Younger than 7 years & 61 & $19 \%$ \\
\hline & Both below and above 7 years & 5 & $2 \%$ \\
\hline & Older than 7 years & 45 & $14 \%$ \\
\hline & Grand Total & 315 & $100 \%$ \\
\hline
\end{tabular}

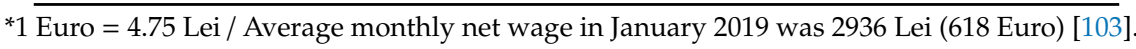

\subsection{Model Assessment}

The model was then assessed in two stages: the assessment of the measurement model and then of the structural model. The measurement model was assessed for internal consistency and reliability. Table 4 shows the values for the outer loading, composite reliability (CR) and average variance extracted (AVE). ad a collinearity problem with ENV_3, and was removed as it had the highest value.

Table 4. Measurement model assessment.

\begin{tabular}{ccccc}
\hline Variables and indicators & FL & VIF & CR & AVE \\
\hline Health consciousness $(H C)$ & & & $\mathbf{0 . 8 8 5}$ & $\mathbf{0 . 7 2}$ \\
\hline $\begin{array}{c}\text { I am concerned about the type and amount of nutrition in the } \\
\text { food that I consume daily }\end{array}$ & 0.802 & 1.597 & & \\
$\begin{array}{c}\text { Organic food is good for one's health } \\
\text { Food Safety Concern }(\boldsymbol{F S})\end{array}$ & 0.866 & 1.812 & & \\
I am willing to shop often in order to eat as healthy as possible & 0.876 & 1.927 & & $\mathbf{0 . 7 3}$ \\
\hline $\begin{array}{c}\text { Nowadays most foods contain residues from chemical sprays } \\
\text { and fertilizers }\end{array}$ & 0.788 & 1.909 & & \\
$\begin{array}{c}\text { I'm very concerned about the amount of artificial additives and } \\
\text { preservatives in food }\end{array}$ & 0.873 & 3.161 & & \\
The quality and safety of food nowadays concerns me & 0.916 & 3.803 & & \\
Organic food is safe to eat & 0.837 & 1.796 & & \\
\hline
\end{tabular}


Table 4. Cont.

\begin{tabular}{|c|c|c|c|c|}
\hline Variables and indicators & FL & VIF & CR & AVE \\
\hline Quality $(Q)$ & & & 0.871 & 0.585 \\
\hline Organic products are fresh & 0.858 & 2.991 & & \\
\hline Organic products will have a good taste & 0.878 & 3.53 & & \\
\hline Organic products don't contain chemicals & 0.856 & 2.649 & & \\
\hline Organic products are nutritious & 0.876 & 2.955 & & \\
\hline Organic products have a longer shelf life * & -0.399 & 1.167 & & \\
\hline Organic products are perishable * & 0.576 & 1.445 & & \\
\hline Organic products have a pleasant smell & 0.774 & 2.049 & & \\
\hline Environmental Concern (EC) & & & 0.961 & 0.859 \\
\hline The balance of nature is very delicate and can be easily upset. & 0.891 & 2.847 & & \\
\hline Human beings are severely abusing the environment. ${ }^{* *}$ & 0.943 & 5.624 & & \\
\hline $\begin{array}{c}\text { Humans must maintain the balance with nature in order to } \\
\text { survive. }\end{array}$ & 0.944 & 5.072 & & \\
\hline $\begin{array}{l}\text { Human interferences with nature often produce disastrous } \\
\text { consequences. }\end{array}$ & 0.929 & 4.695 & & \\
\hline Social consciousness (SC) & & & 0.988 & 0.977 \\
\hline By buying organic products one incourages the local economy ** & 0.988 & 10.973 & & \\
\hline $\begin{array}{l}\text { By buying organic products one supports the development of } \\
\text { the local economy }\end{array}$ & 0.988 & 10.973 & & \\
\hline Personal attitude (PA) & & & 0.961 & 0.83 \\
\hline I think that purchasing organic food is a good idea. & 0.9 & 3.768 & & \\
\hline I think that purchasing organic food is important. & 0.924 & 4.868 & & \\
\hline I think that purchasing organic food is beneficial ** & 0.938 & 5.43 & & \\
\hline I think that purchasing organic food is wise. & 0.91 & 4.252 & & \\
\hline I think that purchasing organic food is favourable. & 0.882 & 3.531 & & \\
\hline Subjective Norms (SN) & & & 0.93 & 0.77 \\
\hline $\begin{array}{l}\text { My family thinks that I should buy organic products rather than } \\
\text { non-organic ones. }\end{array}$ & 0.818 & 1.858 & & \\
\hline $\begin{array}{c}\text { Most people I value would buy organic products rather than } \\
\text { non-organic products. }\end{array}$ & 0.892 & 3.024 & & \\
\hline People I value think I should buy organic products. & 0.914 & 3.704 & & \\
\hline $\begin{array}{l}\text { Most friends whose opinions regarding diet are important to } \\
\text { me, think that I should buy organic products. }\end{array}$ & 0.882 & 2.745 & & \\
\hline Lifestyle (LS) & & & 1 & 1 \\
\hline Purchasing organic products makes me feel superior. & 1 & 1 & & \\
\hline Buying Intention (BI) & & & 0.925 & 0.804 \\
\hline I intend to consume organic products in the future & 0.91 & 3.343 & & \\
\hline $\begin{array}{l}\text { I am always interested in buying more organic food for the } \\
\text { family's needs }\end{array}$ & 0.947 & 4.266 & & \\
\hline $\begin{array}{l}\text { I always intend to look for organic foods, although outside the } \\
\text { city }\end{array}$ & 0.829 & 1.924 & & \\
\hline Actual Buying Behaviour (BB) & & & 0.919 & 0.792 \\
\hline I have been a regular buyer of organic foods & 0.907 & 2.808 & & \\
\hline $\begin{array}{l}\text { I still buy organic food even though conventional alternatives } \\
\text { are on sale }\end{array}$ & 0.932 & 3.359 & & \\
\hline I never mind paying premium price for organic products & 0.828 & 1.85 & & \\
\hline Perceived Behavioral Control (PBC) & & & 0.901 & 0.752 \\
\hline $\begin{array}{c}\text { If I wanted to, I could buy organic products instead of } \\
\text { conventional ones. }\end{array}$ & 0.896 & 2.321 & & \\
\hline I think it is easy for me to buy organic products. & 0.869 & 2.115 & & \\
\hline It is mostly up to me whether or not to buy organic products. & 0.836 & 1.692 & & \\
\hline
\end{tabular}


Except for two items, all the outer loadings were above the 0.7 threshold. The two items regarding shelf life and perishability that were below the threshold value were excluded. The AVE and CR scores were above the cut-off point of 0.50 and 0.70 respectively, indicating that the measurement model was internally consistent [112]. Collinearity was assessed by using the variance inflation factor (VIF). As items 3 and 4 in the personal attitude construct exceeded the threshold value of 5 , the one with the highest values (item PERS_ATT_3) was eliminated. Both items of the social consciousness construct had very high collinearity meaning that they were measuring the same construct. One was eliminated (SOC_1). Variable ENV_2 h.

The discriminant validity was assessed by using the heterotrait-monotrait ratio (HTMT) of correlation (see Table 5) as per [114]. All HTMT ratios were below 0.85 , indicating that the measurement model has discriminant validity. The Cronbach's alpha values for all constructs are above 0.70 confirming the internal consistency of the outer model.

Table 5. Heterotrait-monotrait ratio for the analysed sample.

\begin{tabular}{ccccccccccc}
\hline & BI & BB & EC & FS & HC & LS & PBC & PQ & PA & SC \\
\hline BB & 0.809 & & & & & & & & & \\
EC & 0.486 & 0.396 & & & & & & & & \\
FS & 0.656 & 0.505 & 0.762 & & & & & & & \\
HC & 0.799 & 0.609 & 0.621 & 0.83 & & & & & & \\
LS & 0.126 & 0.104 & 0.064 & 0.044 & 0.069 & & & & \\
PBC & 0.587 & 0.713 & 0.512 & 0.499 & 0.574 & 0.062 & & & \\
Q & 0.618 & 0.513 & 0.629 & 0.755 & 0.729 & 0.051 & 0.556 & & & \\
PA & 0.757 & 0.515 & 0.515 & 0.6 & 0.649 & 0.139 & 0.481 & 0.707 & & \\
SC & 0.498 & 0.378 & 0.589 & 0.632 & 0.544 & 0.006 & 0.46 & 0.658 & 0.573 & \\
SN & 0.731 & 0.603 & 0.343 & 0.48 & 0.656 & 0.194 & 0.49 & 0.578 & 0.633 & 0.456 \\
\hline
\end{tabular}

BI-Buying Intention, BB-Buying behaviour, EC-Environmental Concerns, FS—Food Safety, HC—Health Consciousness, LS-Lifestyle, PBC-Perceived Behavioural Control, PQ-Perception of quality, PA-Personal Attitude, SN-Social Consciousness, $\mathrm{SN}-$ Subjective Norms.

\subsection{Structural Model Assessment}

After the measurement model's reliability and validity were confirmed, the structural model was evaluated. The bootstrapping method was run using 5000 samples and bias-corrected and accelerated (BCa) confidence intervals with two-tailed significance at a 0.05 level. Pairwise deletion was used for handling missing values in order to preserve as much information as possible. There were no collinearity issues in the structural model as resulting from the analysis of the VIF values. The path relationships, coefficients and significance are presented in Table 6.

The adjusted coefficient of determination $\left(\mathrm{R}^{2}\right.$ adj), or the variance explained by the endogenous constructs for the buying intention is moderately high $\left(R^{2}\right.$ adj $\left.=0.668\right)$. This means that more than $66 \%$ of the variance in buying intention can be explained by PBC, health benefits, personal attitude, subjective norms and customer values. The variance in buying behaviour is explained by buying intention in a proportion of almost $50 \%\left(R^{2}\right.$ adj $\left.=0.493\right)$. Consumer values explain $52 \%$ of variance in the personal attitude $\left(R^{2}\right.$ adj $\left.=0.524\right)$. When considering the effect size $\left(f^{2}\right)$ we see that personal attitude has a medium effect on buying intention $\left(f^{2}=0.159\right)$, while buying intention has a high effect on buying behaviour $\left(f^{2}=0.980\right)$. The other variables have a low or no effect (Table 6 ) 
Table 6. Path relationships, coefficients values with their significance levels and confidence intervals.

\begin{tabular}{|c|c|c|c|c|c|}
\hline Path & $\beta$ & $\begin{array}{l}\text { Bias Corrected } \\
\text { CI }\end{array}$ & P Values & $\begin{array}{l}\text { Effect } \\
\text { Size }\end{array}$ & $\begin{array}{l}\text { Hypothesis } \\
\text { Confirmed }\end{array}$ \\
\hline $\begin{array}{l}\text { Buying Intention -> Buying } \\
\text { behaviour (H10) }\end{array}$ & 0.698 & [0.625-0.747] & $<0.001$ & 0.98 & Yes \\
\hline $\begin{array}{l}\text { Environmental Concerns -> } \\
\text { Buying Intention }(\mathrm{H} 2 \mathrm{~b})\end{array}$ & 0.012 & {$[-0.084-0.122]$} & 0.820 & 0.001 & No \\
\hline $\begin{array}{l}\text { Environmental Concerns -> } \\
\text { Personal Attitude (H2a) }\end{array}$ & 0.126 & [0.007-0.261] & 0.047 & 0.017 & Yes \\
\hline $\begin{array}{c}\text { Food Safety }->\text { Buying Intention } \\
\qquad(\mathrm{H} 3 \mathrm{~b})\end{array}$ & 0.131 & {$[-0.002-0.248]$} & 0.041 & 0.017 & Yes \\
\hline $\begin{array}{c}\text { Food Safety }->\text { Personal Attitude } \\
\qquad(\mathrm{H} 3 \mathrm{a})\end{array}$ & 0.002 & {$[-0.129-0.15]$} & 0.974 & 0 & No \\
\hline $\begin{array}{l}\text { Health Consciousness -> Buying } \\
\text { Intention }(\mathrm{H} 1 \mathrm{~b})\end{array}$ & 0.325 & [0.193-0.451] & $<0.001$ & 0.084 & Yes \\
\hline $\begin{array}{c}\text { Health Consciousness -> Personal } \\
\text { Attitude (H1a) }\end{array}$ & 0.178 & [0.067-0.303] & 0.003 & 0.03 & Yes \\
\hline $\begin{array}{c}\text { Lifestyle }->\text { Buying Intention } \\
(\mathrm{H} 5 \mathrm{~b})\end{array}$ & 0.043 & {$[-0.027-0.117]$} & 0.261 & 0 & No \\
\hline $\begin{array}{c}\text { Lifestyle }->\text { Personal Attitude } \\
(\mathrm{H} 5 \mathrm{a})\end{array}$ & 0.108 & [0.027-0.167] & 0.003 & 0.024 & Yes \\
\hline $\begin{array}{c}\text { Perceived Behavioural Control -> } \\
\text { Buying Intention (H9) }\end{array}$ & 0.138 & [0.036-0.226] & 0.006 & 0.038 & Yes \\
\hline $\begin{array}{c}\text { Perception of quality -> Buying } \\
\text { Intention }(\mathrm{H} 4 \mathrm{~b})\end{array}$ & 0.098 & {$[-0.018-0.208]$} & 0.109 & 0.002 & No \\
\hline $\begin{array}{c}\text { Perception of quality -> Personal } \\
\text { Attitude (H4a) }\end{array}$ & 0.407 & [0.286-0.512] & $<0.001$ & 0.147 & Yes \\
\hline $\begin{array}{l}\text { Personal Attitude -> Buying } \\
\text { Intention (H7) }\end{array}$ & 0.345 & [0.225-0.449] & $<0.001$ & 0.159 & Yes \\
\hline $\begin{array}{c}\text { Social Consciousness -> Buying } \\
\text { Intention }(\mathrm{H} 6 \mathrm{~b})\end{array}$ & -0.004 & {$[-0.105-0.099]$} & 0.941 & 0.004 & No \\
\hline $\begin{array}{l}\text { Social Consciousness -> } \\
\text { Personal Attitude (H6a) }\end{array}$ & 0.138 & [0.042-0.243] & 0.010 & 0.022 & Yes \\
\hline $\begin{array}{l}\text { Subjective Norms -> Buying } \\
\text { Intention (H8) }\end{array}$ & 0.244 & [0.15-0.347] & $<0.001$ & 0.099 & Yes \\
\hline
\end{tabular}

\section{Discussion and Conclusions}

The model's explanatory power was assessed by means of the $\mathrm{R}^{2}$ measure [115]. The $\mathrm{R}^{2}$ values for the endogenous constructs in the model ranged from $49 \%$ to $67 \%$ showing reasonably high magnitudes [116] and indicating good explanatory power.

In the framework of the theory of planned behaviour, the strong relationship between buying intention and buying behaviour present in other studies $[16,24]$ has also been found in this sample, confirming hypothesis H10. The relationship is statistically significant and has a strong effect size.

Buying intention is significantly influenced by personal attitude, subjective norms and perceived behavioural control confirming hypotheses $\mathrm{H} 7, \mathrm{H} 8$ and $\mathrm{H} 9$. Because the relationship between buying intention and buying behaviour is so strong, buying behaviour is also significantly influenced by these three factors indirectly, through buying intention. These significant relationships make up the theory of planned behaviour that was confirmed in other studies on organic food consumers $[16,18,23,24,27,28]$.

Health consciousness is one of the major elements in the consumer's personal attitude [16,24,26,117]. Our study found that it significantly affects personal attitude as well has buying intention directly (H1a, H1b) that was also found in other research papers, [18,23]. Environmental concerns, although they influence personal attitude (also found in [28]), don't have a direct influence on buying intention, confirming hypothesis $\mathrm{H} 2 \mathrm{a}$ but not $\mathrm{H} 2 \mathrm{~b}$. Other studies [21,23] found that there is a significant relationship between environmental concerns and buying intention. It seems that, in this sample, there is not enough evidence to suggest that environmental concerns, although an important part of the consumer's attitude, doesn't have a significant direct effect on their buying intention.

Food safety on the other hand has been found to have a significant relationship with buying intention as was also found in [118], confirming H3b but not on personal attitude, not confirming H3a. 
Although personal attitude was found to mediate the relationship between food safety and buying intention [117], this relationship is not supported in this sample.

The perception of quality [17], lifestyle [119] and social consciousness [120] on the other hand were found to have a significant effect on personal attitude (confirming H4a, H5a and H6a), but not on buying intention (not confirming H4b, H5b and H6b). Other studies $[25,42,90,121]$ have found that the perception of quality, lifestyle and social consciousness of consumers significantly influence buying intention, but it was not confirmed in this study. This indicates that, even though these factors affect the personal attitude of the organic product consumer, they do not directly influence buying intention.

This research focused on the buying intention of the Romanian organic food consumer. Two frameworks have been chosen that have been found extensively in the research literature: consumer values (health consciousness, environmental concerns, food safety, perception of quality, lifestyle and social consciousness) and the theory of planned behaviour. Although they have been widely studied, the authors did not find any study that would combine the two frameworks together, considering so many consumer values in one model. The theory of planned behaviour states that buying behaviour is significantly influenced by buying intention and buying intention is influenced by personal attitude, social norms and perceived behavioural control. As found in other studies $[23,24,28,70]$, buying intention is affected by a combination of factors that transcend nationality. The theory was supported fully or partially by studies done in Thailand [28], Italy, Finland, UK [70], Turkey, Pakistan, Iran [23], India [24], Tanzania and Kenia [26] and other countries. At the same time, many studies have analysed the relationship between consumer values and personal attitude $[16,17,24-26,28,117]$ as well as directly with buying intention $[18,21,23,25,42,90]$.

\subsection{Implications}

The findings of this study can be translated into some important insight that can be used in the marketing of organic food products. Firstly, it confirms the theory of planned behaviour for this sample of Romanian organic product consumers.

Although environmental concerns, the social impact of organic farming and the consumer's lifestyle are important in defining their personal attitude towards organic products, they do not have a significant direct effect on their buying intention and behaviour respectively. The health and safety aspects of organic products have a significant impact on the buying intention of the consumer while at the same time affecting their personal attitude. Companies, both national and international, can use this information and adapt their marketing strategies, especially promotion and selling, underlying the peoples' benefits when buying organic food products [122]. They could create campaigns to explain the differences between organic and non-organic food products. Sharing information about benefits can generate a positive attitude and increase sales. Another strategy could be to involve personalities, public figures and influencers for word-of-mouth marketing.

Governmental bodies could benefit from understanding the consumer behaviour and create campaigns that increase the awareness on the benefits of using organic food products.

\subsection{Limitations}

Although the study revealed some important findings, researchers should interpret them keeping in mind its limitations. This study used the non-probabilistic methodology of snowball sampling that has its limitations. Even though it helped the authors reach particular online groups of persons interested in organic products, it is a convenience sampling method meaning that it often results in selection bias and may present internal and external validity limitations [123,124]. Although the results cannot be extrapolated to a larger population, they give important insights in the behaviour of the organic product consumer. As this is merely an exploratory study, a future random sample research might minimize bias and increase the validity of the proposed model. 
Another limitation is the unbalance between male and female respondents. In this study most respondents were female. A future study might try to balance the female-to-male-ratio and observe if the model still holds true.

The current study provides a picture of the organic food consumer at this point in time. The consumer behaviour changes over time in trend with new technologies, environmental policies or economical states. A longitudinal study could give a more stable overview of the factors affecting the consumer's behaviour.

In this research the authors focused on the consumers of organic food products. Important information might be revealed by evaluating the behaviour of non-consumers as well. Such a study might provide insight into methods of transforming such non-consumers into consumers.

Author Contributions: Conceptualization, C.F. and S.A.C.; Data curation, V.B.; Formal analysis, V.B.; Investigation, C.F. and S.A.C.; Methodology, C.F., S.A.C. and V.B.; Writing-original draft, C.F. and S.A.C.; Writing-review \& editing, C.F. and S.A.C. All authors have read and agreed to the published version of the manuscript.

Funding: This research received no external funding.

Conflicts of Interest: The authors declare no conflict of interest.

\section{References}

1. Schweisfurth, K.L.; Gottwald, F.T.; Dierkes, M. Towards Sustainable Agriculture and Food Production: A Vision for the Future Viability of Food Production, Processing and Marketing; Schweisfurth-Stiftung: Munich, Germany, 2002.

2. Toncea, I.; Simion, E.; Ioniță Nițu, E.; Alexandrescu, D.; Toncea, V.A. Manual de Agricultură Ecologică, (Suport de Curs). Available online: http://agriculturadurabila.ro/wp-content/uploads/2016/06/manual.pdf (accessed on 23 January 2020).

3. Isenhour, C. On conflicted Swedish consumers, the effort to stop shopping and neoliberal environmental governance. J. Consum. Behav. 2010, 9, 454-469. [CrossRef]

4. Tilman, D. The greening of the green revolution. Nature 1998, 396, 211-212. [CrossRef]

5. Lernoud, J.; Willer, H. Organic agriculture worldwide: current statistics. In The World of Organic Agriculture, Statistics and Emerging Trends; Medienhaus Plump: Rheinbreitbach, Germany, 2019; p. 40.

6. Dobrescu, M. GAIN Report: Positive Prospects for Organic Food and Agriculture in Romania (RO1902); USDA Foreign Agricultural Service: Bucharest, Romania, 2019.

7. Popa, I.D.; Dabija, D.-C. Developing the Romanian Organic Market: A Producer's Perspective. Sustainability 2019, 11, 467. [CrossRef]

8. Laureti, T.; Benedetti, I. Exploring pro-environmental food purchasing behaviour: An empirical analysis of Italian consumers. J. Cleaner Prod. 2018, 172, 3367-3378. [CrossRef]

9. Belch, G.; Belch, M. Advertising and Promotion: An Integrated Marketing Communications Perspective, 8th ed.; McGraw Hill: New York, NY, USA, 2009.

10. Hughner, R.S.; McDonagh, P.; Prothero, A.; Shultz, C.J.; Stanton, J. Who are organic food consumers? A compilation and review of why people purchase organic food. J. Consum. Behav. 2007, 6, 94-110. [CrossRef]

11. Chiciudean, G.O.; Harun, R.; Ilea, M.; Chiciudean, D.I.; Arion, F.H.; Ilies, G.; Muresan, I.C. Organic Food Consumers and Purchase Intention: A Case Study in Romania. Agronomy 2019, 9, 145. [CrossRef]

12. Rana, J.; Paul, J. Consumer behavior and purchase intention for organic food: A review and research agenda. J. Retail. Consum. Serv. 2017, 38, 157-165. [CrossRef]

13. Ajzen, I. From Intentions to Actions: A Theory of Planned Behavior. In Action Control: From Cognition to Behavior; Kuhl, J., Beckmann, J., Eds.; SSSP Springer Series in Social Psychology; Springer: Heidelberg, Germany, 1985; pp. 11-39, ISBN 978-3-642-69746-3.

14. Ajzen, I. The theory of planned behavior. Organ. Behav. Hum. Decis. Proc. 1991, 50, 179-211. [CrossRef]

15. Ajzen, I. The theory of planned behaviour: Reactions and reflections. Psych. Health 2011, 26, 1113-1127. [CrossRef]

16. Tarkiainen, A.; Sundqvist, S. Subjective norms, attitudes and intentions of Finnish consumers in buying organic food. Br. Food J. 2005, 107, 808-822. [CrossRef]

17. Chen, M.-F. Consumer attitudes and purchase intentions in relation to organic foods in Taiwan: Moderating effects of food-related personality traits. Food Qual. Pref. 2007, 18, 1008-1021. [CrossRef] 
18. Aertsens, J.; Verbeke, W.; Mondelaers, K.; Van Huylenbroeck, G. Personal Determinants of Organic Food Consumption: A Review. Br. Food J. 2009, 111, 1140-1167. [CrossRef]

19. Thøgersen, J.; Zhou, Y. Chinese consumers' adoption of a 'green' innovation - The case of organic food. J. Market. Manag. 2012, 28, 313-333. [CrossRef]

20. Irianto, H. Consumers' Attitude and Intention Towards Organic Food Purchase: An Extension of Theory of Planned Behavior in Gender Perspective; Social Science Research Network: Rochester, NY, USA, 2015.

21. Yadav, R.; Pathak, G.S. Intention to purchase organic food among young consumers: Evidences from a developing nation. Appetite 2016, 96, 122-128. [CrossRef]

22. Tuan, T.N.; Vinh, T.T. An exploration in the theory of planned behavior: A case of organic food in Vietnam. Inter. J. Appl. Bus. Econ. Res. 2016, 14, 4951-4972.

23. Asif, M.; Xuhui, W.; Nasiri, A.; Ayyub, S. Determinant factors influencing organic food purchase intention and the moderating role of awareness: A comparative analysis. Food Qual. Pref. 2018, 63, 144-150. [CrossRef]

24. Singh, A.; Verma, P. Factors influencing Indian consumers' actual buying behaviour towards organic food products. J. Cleaner Prod. 2017, 167, 473-483. [CrossRef]

25. Bagher, A.N.; Salati, F.; Ghaffari, M. Factors Affecting Intention to Purchase Organic Food Products among Iranian Consumers. Acad. Market. Stud. J. 2018, 22. Available online: https://www.semanticscholar.org/paper/Factors-Affecting-Intention-to-Purchase-Organic-BagherSalati/662e9cd3d15b0e37b1ba978129dde632c90612be (accessed on 23 January 2020).

26. Wang, X.; Pacho, F.; Liu, J.; Kajungiro, R. Factors Influencing Organic Food Purchase Intention in Developing Countries and the Moderating Role of Knowledge. Sustainability 2019, 11, 209. [CrossRef]

27. Paul, J.; Modi, A.; Patel, J. Predicting green product consumption using theory of planned behavior and reasoned action. J. Retail. Consum. Serv. 2016, 29, 123-134. [CrossRef]

28. Maichum, K.; Parichatnon, S.; Peng, K.-C. Application of the Extended Theory of Planned Behavior Model to Investigate Purchase Intention of Green Products among Thai Consumers. Sustainability 2016, 8, 1077. [CrossRef]

29. Zeithaml, V.A. Consumer Perceptions of Price, Quality, and Value: A Means-End Model and Synthesis of Evidence. J. Market. 1988, 52, 2-22. [CrossRef]

30. Rokeach, M. The Nature of Human Values; Free Press: New York, NY, USA, 1973.

31. Poortinga, W.; Steg, L.; Vlek, C. Values, Environmental Concern, and Environmental Behavior: A Study into Household Energy Use. Environ. Behavior 2004, 36, 70-93. [CrossRef]

32. Jayanti, R.K.; Burns, A.C. The antecedents of preventive health care behavior: An empirical study. J. Acad. Market. Sci. 1998, 26, 6-15. [CrossRef]

33. Newsom, J.T.; McFarland, B.H.; Kaplan, M.S.; Huguet, N.; Zani, B. The health consciousness myth: implications of the near independence of major health behaviors in the North American population. Soc. Sci. Med. 2005, 60, 433-437. [CrossRef] [PubMed]

34. Devcich, D.A.; Pedersen, I.K.; Petrie, K.J. You eat what you are: Modern health worries and the acceptance of natural and synthetic additives in functional foods. Appetite 2007, 48, 333-337. [CrossRef]

35. Basu, A.; Dutta, M.J. The relationship between health information seeking and community participation: The roles of health information orientation and efficacy. Health Community 2008, 23, 70-79. [CrossRef]

36. Lee, K. Opportunities for green marketing: Young consumers. Market. Intel. Plan. 2008, 26, 573-586. [CrossRef]

37. Mostafa, M.M. Gender differences in Egyptian consumers' green purchase behaviour: The effects of environmental knowledge, concern and attitude. Inter. J. Consum. Stud. 2007, 31, 220-229. [CrossRef]

38. Sinnappan, P.; Rahman, A.A. Antecedents of green purchasing behavior among Malaysian consumers. Inter. Bus. Manage. 2011, 5, 129-139. [CrossRef]

39. Radman, M. Consumer consumption and perception of organic products in Croatia. Br. Food J. 2005, 107, 263-273. [CrossRef]

40. Uyttendaele, M.; Franz, E.; Schlüter, O. Food Safety, a Global Challenge. Int. J. Environ. Res. Public Health 2016, 13, 67. [CrossRef]

41. Verdú Jover, A.J.; Lloréns Montes, F.J.; Fuentes, M.D. Measuring perceptions of quality in food products: the case of red wine. Food Qual. Pref. 2004, 15, 453-469. [CrossRef]

42. Mascarello, G.; Pinto, A.; Parise, N.; Crovato, S.; Ravarotto, L. The perception of food quality. Profiling Italian consumers. Appetite 2015, 89, 175-182. [CrossRef] [PubMed] 
43. Grunert, K.G. Food Quality and Safety: Consumer Perception and Demand. Euro. Rev. Agricultural Econ. 2005, 32, 369-391. [CrossRef]

44. Li, G.; Li, G.; Kambele, Z. Luxury fashion brand consumers in China: Perceived value, fashion lifestyle, and willingness to pay. J. Bus. Res. 2012, 65, 1516-1522. [CrossRef]

45. Plummer, J.T. The Concept and Application of Life Style Segmentation. J. Market. 1974, 38, 33-37. [CrossRef]

46. Horley, J. A Longitudinal Examination of Lifestyles. Soc. Ind. Res. 1992, 26, 205-219. [CrossRef]

47. Fullerton, S.; Dodge, H.R. A reassessment of life style and benefits-based segmentation strategies. J. Market. Manage. 1992, 2, 42-46.

48. Bojnec, S.; Petrescu, D.C.; Petrescu-Mag, R.M.; Rădulescu, C.V. Locally Produced Organic Food: Consumer Preferences. Amfiteatru Econ. 2019, 21, 209-227. [CrossRef]

49. Jiménez-Guerrero, J.F.; Gázquez-Abad, J.C.; del Carmen Linares-Agüera, E. Using standard CETSCALE and other adapted versions of the scale for measuring consumers' ethnocentric tendencies: An analysis of dimensionality. BRQ Bus. Res. Q. 2014, 17, 174-190. [CrossRef]

50. Smaiziene, I.; Vaitkiene, R. Country of Origin Effect in a Lithuanian Market of Vitamins and Dietary Supplements. Int. Bus. Res. 2013, 6, 118-133. [CrossRef]

51. Eagly, A.H.; Chaiken, S. The Advantages of an Inclusive Definition of Attitude. Soc. Cogn. 2007, 25, 582-602. [CrossRef]

52. Armitage, C.J.; Conner, M. Efficacy of the theory of planned behaviour: A metaanalytic review. Br. J.Soc. Psych. 2001, 40, 471-499. [CrossRef]

53. Kim, H.-W.; Chan, H.C.; Chan, Y.P. A balanced thinking-feelings model of information systems continuance. Int. J. Human-Comp. Stud. 2007, 65, 511-525. [CrossRef]

54. Ajzen, I. Nature and operation of attitudes. Annu. Rev. Psych. 2001, 52, 27-58. [CrossRef]

55. Agarwal, J.; Malhotra, N.K. An integrated model of attitude and affect: Theoretical foundation and an empirical investigation. J. Bus. Res. 2005, 58, 483-493. [CrossRef]

56. Lavine, H.; Thomsen, C.J.; Zanna, M.P.; Borgida, E. On the Primacy of Affect in the Determination of Attitudes and Behavior: The Moderating Role of Affective-Cognitive Ambivalence. J. Exp. Soc. Psych. 1998, 34, 398-421. [CrossRef]

57. Huda, N.; Rini, N.; Mardoni, Y. The Analysis of Attitudes, Subjective Norms, and Behavioral Control on Muzakki's Intention to Pay Zakah. Int. J. Bus. Soc. Sci. 2012, 3, 271-279.

58. Cialdini, R.B.; Reno, R.R.; Kallgren, C.A. A focus theory of normative conduct: Recycling the concept of norms to reduce littering in public places. J. Personal. Soc. Psych. 1990, 58, 1015-1026. [CrossRef]

59. Miller, P.; Plant, M.; Plant, M. Spreading out or concentrating weekly consumption: alcohol problems and other consequences within a UK population sample. Alcohol Alcohol. 2005, 40, 461-468. [CrossRef] [PubMed]

60. Sheeran, P.; Taylor, S. Predicting Intentions to Use Condoms: A Meta-Analysis and Comparison of the Theories of Reasoned Action and Planned Behavior. J. Appl. Soc. Psych. 1999, 29, 1624-1675. [CrossRef]

61. Bamberg, S.; Hunecke, M.; Blöbaum, A. Social context, personal norms and the use of public transportation: Two field studies. J. Environ. Psych. 2007, 27, 190-203. [CrossRef]

62. Guido, G.; Prete, M.I.; Peluso, A.M.; Maloumby-Baka, R.; Buffa, C. The role of ethics and product personality in the intention to purchase organic food products: A structural equation modeling approach. Int. Rev. Econ. 2010, 57, 79-102. [CrossRef]

63. Keller, K.L. Building Customer-Based Brand Equity: A Blueprint for Creating Strong Brands; Marketing Science Institute: Cambridge, UK, 2001.

64. Ghosh, A. Retail Management; Drydden Press: Chicago, IL, USA, 1990.

65. Blackwell, R.D.; Miniard, P.W.; Engel, J.F. Consumer Behavior; Dryden Press, Harcourt College Publishers: Ft. Worth, TX, USA, 2001.

66. Liobikienė, G.; Mandravickaitè, J.; Bernatonienė, J. Theory of planned behavior approach to understand the green purchasing behavior in the EU: A cross-cultural study. Eco. Econ. 2016, 125, 38-46. [CrossRef]

67. Howard, J. Consumer Behavior: Application of Theory; McGraw-Hill Book Company: New York, NY, USA, 1977.

68. Brown, M.; Pope, N.; Voges, K. Buying or browsing? An exploration of shopping orientations and online purchase intention. Eur. J. Market. 2003, 37, 1666-1684. [CrossRef]

69. Grewal, D.; Krishnan, R.; Baker, J.; Borin, N. The effect of store name, brand name and price discounts on consumers' evaluations and purchase intentions. J. Retail. 1998, 74, 331-352. [CrossRef] 
70. Arvola, A.; Vassallo, M.; Dean, M.; Lampila, P.; Saba, A.; Lähteenmäki, L.; Shepherd, R. Predicting intentions to purchase organic food: The role of affective and moral attitudes in the theory of planned behaviour. Appetite 2008, 50, 443-454. [CrossRef]

71. Wandel, M.; Bugge, A. Environmental concern in consumer evaluation of food quality. Food Qual. Pref. 1997, 8, 19-26. [CrossRef]

72. Grubor, A.; Milicevic, N.; Djokic, N. Serbian Organic Food Consumer Research and Bioeconomy Development. Sustainability 2018, 10, 4820. [CrossRef]

73. Loureiro, M.L.; McCluskey, J.J.; Mittelhammer, R.C. Assessing Consumer Preferences for Organic, Eco-labeled, and Regular Apples. J. Agric. Resour. Econ. 2001, 26, 404-416.

74. Paul, J.; Rana, J. Consumer behavior and purchase intention for organic food. J. Consum. Market. 2012, 29, 412-422. [CrossRef]

75. Vietoris, V.; Kozelová, D.; Mellen, M.; Chreneková, M.; Potclan, J.E.; Fikselová, M.; Kopkáš, P.; Horská, E. Analysis of Consumer Preferences at Organic Food Purchase in Romania. Pol. J. Food Nutr. Sci. 2016, 66, 139-146. [CrossRef]

76. Antonides, G.; van Raaij, W.F. Consumer Behaviour-A European Perspective; Wiley: Chichester, UK, 1998.

77. McEachern, M.G.; McClean, P. Organic purchasing motivations and attitudes: are they ethical? Int. J. Consum. Stud. 2002, 26, 85-92. [CrossRef]

78. Seyfang, G. Ecological citizenship and sustainable consumption: examining local organic food networks. J. Rural Stud. 2006, 22, 383-395. [CrossRef]

79. Cho, S.; Krasser, A. What makes us care? The impact of cultural values, individual factors, and attention to media content on motivation for ethical consumerism. Int. Social. Sci. Rev. 2011, 86, 3-23.

80. Hay, J. The consumer's perspective on organic food. Can. Inst. Food Sci. Technol. J. 1989, 22, 95-99. [CrossRef]

81. Thomas, T.; Gunden, C. Investigating consumer attitudes toward food produced via three production systems: conventional, sustainable and organic. J. Food Agric. Environ. 2012, 10, 132-135.

82. Van Loo, E.; Diem, M.N.; Pieniak, Z.; Verbeke, W. Consumer attitude, knowledge, and consumption of organic yogurt. J. Dairy Sci. 2013, 96, 2118-2129. [CrossRef]

83. Crutchfield, S.R.; Roberts, T. Food safety efforts accelerate in the 1990's. Food Rev. 2000, 23, 44-49. [CrossRef]

84. Woteki, C.E.; Facinoli, S.L.; Schor, D. Keep food safe to eat: healthful food must be safe as well as nutritious. J. Nutr. 2001, 131, 502S-509S. [CrossRef] [PubMed]

85. Crinnion, W.J. Organic foods contain higher levels of certain nutrients, lower levels of pesticides, and may provide health benefits for the consumer. Alter. Med. Rev. 2010, 15, 4-12.

86. Bryła, P. The role of appeals to tradition in origin food marketing: a survey among Polish consumers. Appetite 2015, 91, 302-310. [CrossRef] [PubMed]

87. Bryła, P. Organic food consumption in Poland: Motives and barriers. Appetite 2016, 105, 737-746. [CrossRef] [PubMed]

88. Salleh, M.M.; Ali, S.M.; Harun, E.H.; Jalil, M.A.; Shaharudin, M.R. Consumer's perception and purchase intentions towards organic food products: Exploring attitude among academician. Can. Soc. Sci. 2010, 6, 119-129. [CrossRef]

89. Kahl, J.; Baars, T.; Bügel, S.; Busscher, N.; Huber, M.; Kusche, D.; Rembiałkowska, E.; Schmid, O.; Seidel, K.; Taupier-Letage, B.; et al. Organic food quality: A framework for concept, definition and evaluation from the European perspective. J. Sci. Food Agric. 2012, 92, 2760-2765. [CrossRef]

90. Canavari, M. Current Issues in Organic Food: Italy. In Organic Food Consumers' Choices and Farmers' Opportunities; Springer Science +Business Media: New York, NY, USA, 2007; pp. 171-181.

91. Wood, W.; Hayes, T. Social influence on consumer decisions: Motives, modes, and consequences. J. Consum. Psycho. 2012, 22, 324-328. [CrossRef]

92. Sparks, P.; Shepherd, R. Self-Identity and the theory of planned behavior: Assesing the role of identification with "green consumerism". Soc. Psych. Q. 1992, 55, 388-399. [CrossRef]

93. Conner, M.; Sparks, P. The theory of planned behaviour and health behaviours. In Predicting Health Behaviour: Research and Practice with Social Cognition Models; Open University Press: Buckingham, UK, 1996.

94. Dean, M.; Raats, M.M.; Shepherd, R. Moral Concerns and Consumer Choice of Fresh and Processed Organic Foods. J. Appl. Soc. Psych. 2008, 38, 2088-2107. [CrossRef] 
95. Dean, M.; Raats, M.M.; Shepherd, R. The Role of Self-Identity, Past Behavior, and Their Interaction in Predicting Intention to Purchase Fresh and Processed Organic Food. J. Appl. Soc. Psych. 2012, 42, 669-688. [CrossRef]

96. Zagata, L. Consumers' beliefs and behavioural intentions towards organic food. Evidence from the Czech Republic. Appetite 2012, 59, 81-89. [CrossRef] [PubMed]

97. Robinson, R.; Smith, C. Psychosocial and demographic variables associated with consumer intention to purchase sustainably produced foods as defined by the Midwest Food Alliance. J. Nutr. Educ. Behav. 2002, 34, 316-325. [CrossRef]

98. Dowd, K.; Burke, K.J. The influence of ethical values and food choice motivations on intentions to purchase sustainably sourced foods. Appetite 2013, 69, 137-144. [CrossRef] [PubMed]

99. Yazdanpanah, M.; Forouzani, M. Application of the theory of planned behaviourto predict Iranian students' intention to purchase organic food. J. Clean. Prod. 2015, 107, 342-352. [CrossRef]

100. Olsen, S.O. Antecedents of Seafood Consumption Behavior. J. Aquat. Food Prod. Technol. 2004, 13, 79-91. [CrossRef]

101. Taylor, S.; Todd, P. Decomposition and crossover effects in the theory of planned behavior: A study of consumer adoption intentions. Int. J. Res. Market. 1995, 12, 137-155. [CrossRef]

102. Grunert, S.C.; Juhl, H.J. Values, environmental attitudes, and buying of organic foods. J. Econ. Psych. 1995, 16, 39-62. [CrossRef]

103. Sheppard, B.H.; Hartwick, J.; Warshaw, P.R. The Theory of Reasoned Action: A Meta-Analysis of Past Research with Recommendations for Modifications and Future Research. J. Consum. Res. 1988, 15, 325-343. [CrossRef]

104. Saba, A.; Messina, F. Attitudes towards organic foods and risk/benefit perception associated with pesticides. Food Qual. Pref. 2003, 14, 637-645. [CrossRef]

105. Soper, D.S. A-priori Sample Size Calculator for Structural Equation Models [Software]. Available online: http://www.danielsoper.com/statcalc (accessed on 23 January 2020).

106. Voon, J.P.; Ngui, K.S.; Agrawal, A. Determinants of Willingness to Purchase Organic Food: An Exploratory Study Using Structural Equation Modeling; Social Science Research Network: Rochester, NY, USA, 2011.

107. Michaelidou, N.; Hassan, L.M. The role of health consciousness, food safety concern and ethical identity on attitudes and intentions towards organic food. Int. J. Consum. Stud. 2008, 32, 163-170. [CrossRef]

108. Torjusen, H.; Lieblein, G.; Wandel, M.; Francis, C.A. Food system orientation and quality perception among consumers and producers of organic food in Hedmark County, Norway. Food Qual. Pref. 2001, 12, 207-216. [CrossRef]

109. Roberts, J.A.; Bacon, D.R. Exploring the Subtle Relationships between Environmental Concern and Ecologically Conscious Consumer Behavior. J. Bus. Res. 1997, 40, 79-89. [CrossRef]

110. Berlin, L.; Lockeretz, W.; Bell, R. Purchasing foods produced on organic, small and local farms: A mixed method analysis of New England consumers. Renew, Agric. Food Syst. 2009, 24, 267-275. [CrossRef]

111. Bai, L.; Wang, M.; Gong, S. Understanding the Antecedents of Organic Food Purchases: The Important Roles of Beliefs, Subjective Norms, and Identity Expressiveness. Sustainability 2019, 11, 3045. [CrossRef]

112. Hair, J.F.; Risher, J.J.; Sarstedt, M.; Ringle, C.M. When to use and how to report the results of PLS-SEM. Eur. Bus. Rev. 2019, 31, 2-24. [CrossRef]

113. Hair, J., Jr.; Sarstedt, M.; Hopkins, L.; Kuppelwieser, V.G. Partial least squares structural equation modeling (PLS-SEM): An emerging tool in business research. Eur. Bus. Rev. 2014, 26, 106-121. [CrossRef]

114. Hair, J.F.; Hult, G.T.M.; Ringle, C.M.; Sarstedt, M.; Thiele, K.O. Mirror, mirror on the wall: a comparative evaluation of composite-based structural equation modeling methods. J. Acad. Market. Sci. 2017, 45, 616-632. [CrossRef]

115. Shmueli, G.; Koppius, O.R. Predictive Analytics in Information Systems Research. MIS Q. 2011, 35, 553-572. [CrossRef]

116. Henseler, J.; Ringle, C.M.; Sinkovics, R.R. The use of partial least squares path modeling in international marketing. In New Challenges to International Marketing; Sinkovics, R.R., Ghauri, P.N., Eds.; Advances in International Marketing; Emerald Group Publishing Limited: Bingley, UK, 2009; Volume 20, pp. 277-319, ISBN 978-1-84855-469-6.

117. Çabuk, S.; Tanrikulu, C.; Gelibolu, L. Understanding organic food consumption: attitude as a mediator. Int. J. Consum. Stud. 2014, 38, 337-345. [CrossRef] 
118. Waqas, A.; Hong, C. Study on Consumer Behaviour and Food Safety of Organic Products in Pakistan. E3S Web Conf. 2019, 78, 02021. [CrossRef]

119. Chen, M. Attitude toward organic foods among Taiwanese as related to health consciousness, environmental attitudes, and the mediating effects of a healthy lifestyle. Br. Food J. 2009, 111, 165-178. [CrossRef]

120. Nagy-Pércsi, K.; Fogarassy, C. Important Influencing and Decision Factors in Organic Food Purchasing in Hungary. Sustainability 2019, 11, 6075. [CrossRef]

121. Annunziata, A.; Vecchio, R. Organic Farming and Sustainability in Food Choices: An Analysis of Consumer Preference in Southern Italy. Agric. Agric. Sci. Procedia 2016, 8, 193-200. [CrossRef]

122. Hanganu, I.; Fleseriu, C. Good Practices for Improving Promotion and Sales for Romanian Ecological Agricultural Products. Timisoara J. Econ. Bus. 2019, 12, 71-86. [CrossRef]

123. Cohen, N.; Arieli, T. Field research in conflict environments: Methodological challenges and snowball sampling. J. Peace Res. 2011, 48, 423-435. [CrossRef]

124. Valdez, A.; Kaplan, C.D. Reducing Selection Bias in the Use of Focus Groups to Investigate Hidden Populations: The Case of Mexican-American Gang Members from South Texas. Drugs Soc. 1998, 14, $209-224$. [CrossRef]

(C) 2020 by the authors. Licensee MDPI, Basel, Switzerland. This article is an open access article distributed under the terms and conditions of the Creative Commons Attribution (CC BY) license (http://creativecommons.org/licenses/by/4.0/). 